\title{
"I Shall Fear God Alone and Not Show Favor in Torah": A Conceptual Foundation for Wrestling with Biblical Scholarship
}

David Bigman

The thoughts that I will present in this article began to develop during my studies as a high school student at the Skokie Yeshiva. It was then that I became aware that the doctrine that the entire Torah was dictated by God to Moses seemed in conflict with the plain meaning of the biblical text. I did not dispute the exalted and binding status of the Written Torah, but I did not understand why this belief should require accepting this particular model of its composition. Though many important authorities, including Maimonides, supported contrary opinions, I clung to the understanding that I had reached from a plain reading of the sources.

I was told that questioning the story that the Torah was dictated undercut the foundation of our faith and our ability to prove its truth. On the contrary, I believed that a more complex notion of belief would be more compelling than this simplistic doctrine. Years later, I discovered biblical scholarship in its various forms, and I was astonished at the extent to which it challenged my friends' and students' worldview. In light of my personal experience, I have reformulated the ideas that occurred to me when I was young, and hope that they will help reduce the confusion that biblical scholarship causes many observant Jews. 


\section{The "Dictation" Model of Torah Revelation: "Dictation" according to Maimonides}

The idea that the Torah was dictated to Moses in a single act of revelation, and, therefore, that every word and every verse of the Torah is equal to all others in importance, has become one of the foundational principles of contemporary religious education. This doctrinarian stance needlessly leads to a difficult struggle with biblical criticism. ${ }^{1}$

When did this become a common belief, and what are its roots in rabbinic literature and the writings of the Rishonim? This position was first expressed by Maimonides in his eighth principle of faith. These principles are enumerated in his introduction to Mishnah Sanhedrin 10:

The eighth fundamental principle is that the Torah is from Heaven, that is to say that we believe that this entire Torah which is found in our hands today is the Torah which was given through Moses, and that it is all of divine origin. This means that it all reached him from God in a manner that we metaphorically call "speech." The exact quality of that communication is only known to Moses, may he rest in peace, to whom it came, and that he acted as scribe to whom one dictates and who writes all of it including its chronicles, its narratives, and its commandments. For this reason, he is called "the inscriber." And there is no difference between: "The descendants of Ham: Cush, Mizraim, Put, and Canaan" (Gen. 10:6), or "his wife's name was Mehetabel daughter of Matred" (Gen. 36:39), or "I am the Lord your God" (Deut. 5:6), or "Hear, O Israel! The Lord is our God, the Lord is alone" (Deut. 6:4). For all are of divine origin ${ }^{3}$ and all belong to the Law of God which is perfect, pure, holy, and true. For this reason, in the eyes of the sages, there was no greater unbeliever and heretic than Manasseh because he thought that in the Torah there are grain and chaff and that these chronicles and narratives have no value at all, and that Moses said them on his own. ${ }^{4}$

Following the Rabbis' statement in tractate Bava Batra that the entire Torah was dictated to Moses, which will be examined below, Maimonides created the principle of the uniformity and equality of all the words and verses in the Torah. According to this principle, it is considered heresy to distinguish between narrative frame and content, as well to attribute greater importance to certain parts of the Torah over others. 


\section{The Development of Maimonides' Principle of "Torah from Heaven"}

We must now examine the two assumptions underlying Maimonides' words: First of all, is Maimonides' claim that Moses merely recorded God's words the only view of Moses' role in the giving of the Torah that appears in rabbinic literature? Secondly, was the idea that all the words of the Torah are equally accepted throughout the rabbinic period?

Rather than supporting Maimonides' view, a close study of the rabbinic sources reveals a more complex picture. The Mishnah, in tractate Sanhedrin, chapter 10, enumerates a list of people who have no portion in the world to come: "These are they who have no share in the world to come: he who says that the doctrine of resurrection is not from the Torah and [he that says says] that the Torah is not from heaven." 5

The Babylonian Talmud takes a firm stand on the nature of the revelation of the Torah. It states that the Torah in its entirety was revealed from heaven, and that all who say otherwise are counted among those described by the verse "because he has spurned the word of the Lord" (Num. 15:31):

Another $\left[\right.$ baraita $\left.^{6}\right]$ taught: "Because he has spurned the word of the Lord"-This refers to one who maintains that the Torah is not from heaven. And even if he asserts that the whole Torah is from heaven, excepting a particular verse, which [he maintains] was not uttered by God but by Moses himself, he is included in "because he has spurned the word of the Lord." And even if he admits that the whole Torah is from heaven, excepting a single point, a particular ad majus deduction [kal va-homer], or a certain analogy [gezerah shavah], he is still included in "because he has spurned the word of the Lord."

A simple reading of the Mishnah indicates that the expression "Torah from heaven" at the start of this baraita refers to the Torah's heavenly validity. However, the continuation of the baraita hints that the meaning of the expression changed, and it came to be a description of the method of the transmission of the Torah. The moderate heresy described in the baraita - the statement that a certain verse was not said by God, but rather by Moses-is based on the assumption that all the other verses were spoken by God to Moses. If this statement is so objectionable and so grave, one must conclude that the acceptable and proper statement is that the entire Torah, with no exception, was spoken by God to Moses. This stance is also 
reflected in the debate over the final verses in the book of Deuteronomy that narrate Moses' death. These verses pose a problem for the model that God dictated the entire Torah to Moses, but the Talmud suggests the following resolution:

Joshua wrote the book that bears his name and eight verses of the Torah. This statement is in agreement with the authority who says that eight verses in the Torah were written by Joshua, as it has been taught: "So Moses, the servant of the Lord died there" (Deut. 34:5). Now, is it possible that Moses was alive and wrote "Moses died there"? The truth is, however, Moses wrote up to that point, and Joshua wrote from this point onward. This is the opinion of Rabbi Judah, or, according to others, of Rabbi Nehemiah. Rabbi Simeon said to him: Is it possible that the Torah was missing one letter? And is it not written, "Take this book of Teaching" (Deut. 31:26)! No; what we must say is that up to this point the Holy One, blessed be He, dictated and Moses repeated and wrote, and from this point God dictated and Moses wrote in tears. ${ }^{8}$

Maimonides combines our two sources. The passage in tractate Sanhedrin declares that one who denies that the entire Torah is from heaven despises the word of God. However, the text does not explain what "Torah from heaven" means, even though it is the source of Maimonides' "dictation" model. The passage from tractate Bava Batra deals explicitly with the transmission of the Torah, but it does not address the fundamental question of "Torah from heaven." Taken together, these statements yield the view that the entire Torah was dictated to Moses by God according to the theological principle of "Torah from heaven"; those who reject this principle are indicated by the verse "because he has spurned the word of the Lord." That is to say, in his commentary on the Mishnah cited above, Maimonides created a new idea: that all parts of the Torah are unified and equal.

\section{The Halakhic Attitude toward the Decalogue}

The primary litmus test of the view that all parts of the Torah are equal is the halakhic attitude toward the biblical passages containing the revelation at Sinai and the Decalogue. With regard to this section of the Torah in particular, some posekim expressed concern about customs that convey a special attitude 
toward these chapters. When Maimonides was asked about the practice of standing when the Decalogue is read, he issued the following responsum:

Wherever there is a custom to stand [during the reading of the Decalogue], one should stop people from doing this, lest there result a loss of faith, when they come to believe that parts of the Torah are greater than others, and this is very grave, and one should close off any possible opening to this bad belief.... And the sectarians are those for whom the fundamentals of our holy Torah are confused, and among them is one who says that the Torah is not from heaven. [The Rabbis] already explained that there is no difference between one who repudiates the entire Torah and one who repudiates one verse, saying that Moses said it himself. There are sectarians who believe that none of the Torah is from heaven except the Decalogue and that the rest of the Torah was spoken by Moses himself, and it is because of this that the daily recitation [of the Decalogue] was abolished. And one should not under any circumstances assign greater status to one part of the Torah over others. You may investigate our words on this subject in the commentary on the Mishnah in perek Helek.-This is the writing of Moses [Maimonides]. ${ }^{9}$

Maimonides adopted the position that it is impermissible to stand during the reading of the Decalogue in opposition to those sectarians who rejected the heavenly origin of the rest of the Torah. While Maimonides' position is based on the talmudic passage that we will consider below, it goes beyond the passage's plain meaning by stating that all the verses of the Torah are entirely equal. Since this reading is forced, it is likely that Maimonides intended this strong statement as a polemic against heretical sects, and that it does not reflect his true opinion. His source is Babylonian Talmud tractate Berakhot 12a:

They recited the Decalogue, the Shema, the sections "Now, if you obey the Lord your God" (Deut. 11:13-21), and "And the Lord said" (Num. 15:37-41), "True and firm," the Avodah, and the priestly blessing. Rabbi Judah said in the name of Samuel: Outside the Temple people wanted to do the same, but [the recitation of the Decalogue] had already been abolished on account of the contentions of the sectarians.... Rabba b. bar Hanah thought to institute it in Sura, but Rav Hisda said to him: It has already been abolished on account of the contentions of the sectarians. Amemar thought to institute it in Nehardea, but Rav Ashi said 
to him: They already abolished it on account of the contentions of the sectarians.

The Jerusalem Talmud has a parallel passage:

\begin{abstract}
Rabbi Matana and Rabbi Samuel b. Nachman both say: By law one should read the Decalogue every day. Why is it not read? On account of the claims of the sectarians, lest they say: These alone were given to Moses at Sinai. ${ }^{10}$
\end{abstract}

The difference between these two passages is that the Babylonian Talmud tells the story of attempts to establish the recitation of the Decalogue outside the Temple as part of the Shema service, following the customary practice when the Temple was standing, while the Jerusalem Talmud adheres to a basic presumption that one should recite the Decalogue every day. In any case, many commentators equated these passages and understood, rightly, that, if not for the sectarians' claims, the Rabbis mentioned in the Babylonian Talmud would have established the recitation of the Decalogue and afforded it its rightful, meaningful place. ${ }^{11}$ Both passages recognize the Decalogue's elevated standing, but are wary of the sectarians who want to entirely invalidate the status of the other commandments.

The debate concerning the proper place of the Decalogue was reopened after the Talmudic period. Jews in later generations sought to reaffirm the special status of the Decalogue. In response to this desire, Rabbi Shlomo b. Aderet (Rashbah, 1235-1310) entirely prohibited the communal recitation of the Decalogue, relying on Shmuel's statement in tractate Berakhot, even though the original statement relates only to the Shema service. ${ }^{12}$ Rabbi Joseph Karo (1488-1575), in the Shulhan Arukh, recognized the unique status of the Decalogue and other portions of the Torah, and he recommended reciting them every day. Rabbi Moses Isserles (Ramah, 1520-1572) also recognized their uniqueness, but, in accordance with Rashbah's responsum, he noted that it is prohibited to recite the Decalogue in public. Similarly, Rabbi David Ha-Levi Segal (Taz, 1586-1667) and Rabbi Abraham Gombiner (Magen Avraham, 1635-1682) ruled that reciting the Decalogue is only permitted in private.

\title{
The Unique Status of the Decalogue
}

All the posekim agree that the Decalogue has a superior status, whether because of its content or because it was given in a special revelation. In fact, this special 
status is the reason why people might risk thinking that only the Decalogue is true. This position is quite far from the spirit of Maimonides' approach in his commentary on tractate Sanhedrin and in the responsum cited above, where he is unwilling to acknowledge any difference in status among the verses of the Torah.

The view of the posekim that the revelation at Sinai and the Decalogue have privileged status is supported by countless sources that discuss their uniqueness. For example, the Mekhilta de-Rabbi Yishmael distinguishes between divine speech at Sinai and statements in the rest of the Torah:

"All these words" (Exod. 20:1): Scripture hereby teaches that God spoke the Decalogue with one utterance-something impossible for creatures of flesh and blood—for it says: "And God spoke all these words, saying." If so, why then is it said: "I am the Lord your God.... You shall have no other gods besides Me" (20:2-3)? Rather, it teaches that the Holy One, blessed be He, after having said all the Decalogue in one utterance, repeated them, saying each commandment separately. One might think that the other commandments of the Torah were also spoken all with one utterance. Therefore it says "these." These words only were spoken in one utterance, but all the rest of the commandments of the Torah were spoken separately, each one by itself. ${ }^{13}$

An additional example of the recognition of the importance and gravity of the Decalogue is found in Eikhah Rabbah. This passage interprets the first verse of Lamentations, and explains the background of the book in the abandonment of the Decalogue: “Alas! Lonely sits' (Lam. 1:1) —Alone from those who abide by the Decalogue, which you abandoned. [This is derived from the fact that] the numerical value of badad, "alone," is ten. ${ }^{14}$

Similarly, Pesikta de-Rav Kahana explains the payment of the half shekel (equivalent to ten gerahs) that saved the Israelites from the plague as a ransom for abandoning the Decalogue: 'This is what everyone who is entered in the records shall pay' (Exod. 30:13)—Rabbi Joshua b. Rabbi Nehemiah said in the name of Rabbi Yohanan b. Zakai: Because the Israelites transgressed the Decalogue, each of them must give ten gerahs. ${ }^{15}$

It is significant that the rabbinic approach, which was completely accepted by the posekim, views the Sinaitic revelation as a special, onetime event, and the Decalogue as a supremely important divine utterance. Of course, they believed that the rest of the Torah was also divine truth, but it did not occur to them that 
a verse such as "The descendants of Ham: Cush, Mizraim, Put, and Canaan" (Gen. 10:5) was equivalent to "I am the Lord" (Exod. 20:2). Moreover, it seems that the question of how the rest of the Torah was transmitted did not trouble them. They were not compelled to depict the dictation of the entire Torah at Sinai as Maimonides did.

Unlike the view professed today, the importance that tradition ascribes to the Sinai revelation and the Decalogue points to a recognition that there are different levels of revelation, and that certain verses are relatively more important than others. ${ }^{16}$

\section{Uncovering Different Kinds of Torah Passages: Sections of the Torah that have Special Status in Rabbinic Literature}

Rabbinic literature exhibits several approaches to the status of the revelation of different parts of the Torah-approaches that differ substantially from that of Maimonides. I have chosen several examples from among the many sources in which this phenomenon is particularly significant.

We will begin with the approach found in the Jerusalem Talmud, in which the singularity of particular parts of the Torah is expressed in the obligation to recite blessings before and after reading them:

Rabbi Jonathan the Scribe came here from Gufta. He saw Bar Avuna the Scribe reading the Song of the Well and reciting blessings before and after it. He said to him: Is this done? He responded: Do you still not know this? All [biblical] songs require blessings before and after them. It was asked of Rabbi Simon. Rabbi Simon said in the name of Rabbi Joshua b. Levi: The only passages that require blessings before and after them are the Song of the Sea, the Decalogue, the curses in Leviticus, and the curses in Deuteronomy. Rabbi Abahu said: I had not heard this, but these words make sense in connection with the Decalogue. Rabbi Jose said in the name of Rabbi Bon: The last eight verses of Deuteronomy require blessings before and after them. ${ }^{17}$

In the parallel passage in the Babylonian Talmud, there is a narrower reference to the topic with a different halakhic implication:

A tanna taught: He commences his reading [of the blessings and curses that are read on fast days] with the verse before them and concludes it 
with the verse after them. Abaye said: This is taught only with respect to the curses in Leviticus, but a break may be made with respect to the curses in Deuteronomy. What is the reason? In the former Israel are addressed in the plural, and Moses spoke what God said. But the latter address Israel in the singular, and Moses said them in his own name. ${ }^{18}$

This source notes that there are verses in the Torah that were spoken by Moses and not by God. This fits the plain meaning of the biblical texts, but it is the very statement that the Gemara in tractate Sanhedrin defines as despising the word of the Lord: And even if he asserts that the whole Torah is from heaven, excepting a particular verse that [he maintains] was not uttered by God but by Moses himself, he is included in "because he has spurned the word of the Lord." ${ }^{19}$

The commentators sensed the contradiction between the plain meaning of the biblical texts and the Gemara in tractate Sanhedrin, or else just the contradiction between the Talmudic passages. Nachmanides (1194-1270) and others claimed that although Moses spoke the words himself, at some stage God had them written down and they thus became words of the living God. ${ }^{20}$ Rabbi Nissim of Gerona (Ran, 1320-1376) followed a similar approach. However, in light of Abaye's ruling, which argues that there is a difference between these verses and the rest of the Torah, he claims that at the end of the process a difference in status remained. ${ }^{21}$

\section{"Torah from Heaven" or "The Law of Moses from Sinai"}

The expressions "Torah from heaven" and "the law of Moses from Sinai" appear in rabbinic literature with various meanings that do not fit the image of the "dictation" model of the Torah. In some instances, the word "Torah" describes only parts of the Pentateuch. The expression "the law of Moses from Sinai" is applied, at times, to laws that were not revealed at Mount Sinai.

The passages that discuss Moses' rebuke of the people in the book of Deuteronomy are not the only ones that attribute different degrees of revelation to different verses. The following midrash from Va-yikra Rabbah describes the reception of the Torah in several stages and through different types of revelation:

A different interpretation: "The Lord called to Moses and spoke to him" (Lev. 1:1) - From here they said that a boor is better than any scholar who 
does not have sense. Know that this is true: Come and learn from Moses, the father of wisdom, father of the prophets, who brought Israel out of Egypt and by whose hand several miracles were performed in Egypt, "wondrous deeds in the land of Ham, awesome deeds at the Sea of Reeds" (Ps. 106:22). He went to the highest heavens and brought the Torah from heaven, and he was involved in the building of the Tabernacle. Yet even he did not go in to the Holy of Holies until He called him, as it says: "The Lord called to Moses and spoke to him."22

Va-yikra Rabbah tells the story of the formation of the Torah in a completely different way than the Babylonian Talmud in tractate Megillah. According to the authors of this midrash, the Torah given at Sinai is either the Book of the Covenant and the commandments relating to the Tabernacle, or Genesis and the events preceding the revelation at Sinai. This midrash argues that the "Torah" that was given from heaven at Sinai does not include the divine revelation to Moses described in the book of Leviticus, or any later, post-revelation narratives.

The difference between these views is reminiscent of the debate mentioned in the Babylonian Talmud: "Rabbi Ishmael said: The general principles were given at Sinai, and the details at the Tent of Meeting. But Rabbi Akiva said: The general principles and the details were given at Sinai, repeated in the Tent of Meeting, and repeated a third time in the plains of Moab."23

\section{"The Torah" as a Term Referring to Particular Revelations or Sections}

The rabbinic sources that we have seen so far suggest that the Torah was given in various revelations, as the plain sense of the verses indicates. In different places, the Rabbis used the expression "Torah from Sinai" and "Torah from heaven" in order to comment on a particular revelation, or, alternatively, on the truth of certain sections of the Torah, and not as a precise description of the means of their transmission. We have seen this usage in the posekim, the Rishonim, and the Aharonim with respect to the status of the Decalogue. In Sifrei Devarim it is clear that the Rabbis call only the revelation at Sinai "Torah from heaven": "A different interpretation: 'Give ear, O heavens, let me speak' (Deut. 32:1) — This refers to the fact that the Torah was given from heaven, as it says: 'You yourselves saw that I spoke to you from the very heavens' (Exod. 20:19). 'Let the earth hear the words I utter' (Deut. 32:1) —on which the Israelites stood and said, 'All that the Lord has spoken we will faithfully do' (Exod. 24:7)."24 
Similarly, Rabbi Joshua b. Levi, refers to parsahat Mishpatim alone as “Torah." Another source, Babylonian Talmud tractate Gittin 70a, argues that the Torah was given in individual, unsealed scrolls, and that the whole Torah was therefore not given at Sinai.

The Babylonian Talmud in tractate Sanhedrin interpreted the idea of "Torah from heaven" that appears in the Mishnah as a description of the means of transmission of the Torah. However, as is generally the case in rabbinic literature, this is not always what the expressions "from Heaven" and "from Sinai" indicate. In Kohelet Rabbah, Rabbi Nehemiah includes the additional writings (the Tosafot) of the house of Rabbi and Rabbi Nathan, and "even what a senior student will say to his teacher in the future," within the rubric of the "law of Moses from Sinai”:

\begin{abstract}
Rabbi Nehemiah says: "Thus the greatest advantage (yitron) in all the land is his" (Eccles. 5:8) - Things that seem extra (meyutarin) in the Torah, such as the additional writings of the house of Rabbi and the additional writings of Rabbi Nathan, and the laws of sojourners and slaves-even these were given to Moses at Sinai. And, for example, the laws of tzitzit, tefillin, and mezuzot are included in "Torah," as is written, "And the Lord gave me the two tablets of stone inscribed by the finger of God, with the exact words" (Deut. 9:10); and it says there "all the instructions that I enjoin upon you" (Deut. 8:1). Not only "all" but "according to all"; not only "words" but "the words"; not only "commandments" but "the commandments." This means that Scripture, the Mishnah, the law, the Talmud, additional writings, legends, and even what a senior student will say to his teacher in the future were all given to Moses at Sinai. ${ }^{25}$
\end{abstract}

Likewise, the Jerusalem Talmud also implies that there are legal rulings that are considered "law of Moses from Sinai": Rabbi Lazer said: "Everywhere where they learned truth (be-emet), it is the law of Moses from Sinai." 6

The problem is that the phrase "they spoke in truth (be-emet)" is also applied to things that are clearly rabbinic in origin. Thus, Rabbi Asher b. Yehiel (Rosh, ca. 1259-1327), referencing Rabbi Isaac b. Samuel of Dampierre (Ri the Elder, 1115-1184), writes:

Ri says that we do not find anywhere that the rules of what invalidates a ritual bath are the "law of Moses from Sinai." And if we do find a source that states this, we should interpret it in accordance with the meaning of 
this phrase in the baraita in tractate Hagigah: "There is a law of Moses from Sinai that the lands of Ammon and Moab are subject to the laws of the poor tithe in the sabbatical year," ${ }^{27}$ which means only: This is a clear ruling, as if it were a law given to Moses at Sinai. Moreover, any time the term "in truth" (be-emet) is used, it is a law [of Moses from Sinai, so to speak], as it says throughout the Talmud regarding matters of rabbinic origin. ${ }^{28}$

\section{Echoes of Maimonides' View in Medieval Biblical Interpretation: Nachmanides}

The two sections of the Babylonian Talmud that describe the writing of the Torah as dictation by God profoundly influenced later commentators. Nachmanides, for example, wrote in an introduction to his commentary on the book of Genesis:

But Moses wrote the history of all former generations and his own genealogy, history, and experiences in the third person. Therefore he says, "The Lord spoke to Moses, saying" (Exod. 6:10, etc.) as if he were speaking about another person. And because it is so, Moses is not mentioned in the Torah until his birth, and even at that time he is mentioned as if someone else was speaking about him. Now do not find a difficulty in the matter of Deuteronomy, wherein he does speak about himself"I pleaded" (Deut. 3:23), "I prayed to the Lord" (9:26), "I said" (1:9, etc.) - for the beginning of that book reads, "These are the words that Moses addressed to all Israel" (1:1). Thus throughout Deuteronomy he is like one who narrates things in the exact language in which they were spoken. The reason for the Torah being written in this form is that it preceded the creation of the world, and, needless to say, the birth of Moses, in keeping with the Kabbalah's statement that it was written in black fire on white fire. Thus Moses was like a scribe who copies from an ancient book, and therefore he wrote anonymously. However, it is true and clear that the entire Torah-from the beginning of the book of Genesis to [the last verse in Deuteronomy,] "before all Israel" (34:12)_reached the ear of Moses from the mouth of the Holy One, blessed by He, just as it is said elsewhere [where Baruch the scribe describes his writing the words of Jeremiah]: "He himself recited all those words to me, and I would write them in the scroll in ink" (Jer. 36:18). ${ }^{29}$ 
In this passage, Nachmanides struggles with one of the obvious problems that the plain meaning of the biblical texts creates for the "dictation" model. If Moses wrote the Torah, why is the book of Genesis narrated by an omniscient third person narrator, while the book of Deuteronomy is narrated by Moses in the first person? Nachmanides explains that the earlier parts of the Torah are related by an omniscient narrator because Moses is not mentioned in the Torah until the moment of his birth, "his entry into the story." He also explains why there is no gap between Moses' knowledge and the contents of the Torah: the entire Torah preceded the creation of the world, and was dictated to Moses by God. It is important to note that Nachmanides elaborates considerably on the quoted passage. While the text merely states "Moses wrote," Nachmanides argues that the entire Torah preceded the world, and that Moses wrote exactly what God said, just as Baruch the Scribe wrote exactly what Jeremiah said. The solution that Nachmanides proposes explains the changes in genre within the Torah in accordance with the Babylonian Talmud's model of dictation. It creates a harmonized picture that obscures the contradictions between this model and the plain meaning of the biblical texts. However, Nachmanides does not claim that all the verses of the Torah are equal. ${ }^{30}$

\section{Abarbanel}

Don Isaac Abarbanel (1437-1508), following Nachmanides, explains more broadly that the prophets themselves composed all the poetic passages in the prophetic books:

From this you should know and understand that every poem found in the words of the prophets is something they composed themselves with divine inspiration and not something they saw in prophecy. ... Poetry is the prophet's work, composed according to the holy spirit within him, not a vision shown to him in prophecy. Therefore, Scripture always attributes [the poem] to the prophet who composed it, as it says in the Song of the Well, “Then Israel sang” (Num. 21:17); [and likewise:] "Deborah and Barak son of Abinoam sang" (Judg. 5:1); "The Song of Songs, by Solomon" (Songs 1:1); and Isaiah says, "Let me sing for my beloved" (Isa. 5:1) — the song is attributed to him as the one who composed it. So, too, in the case of the Song of the Sea it says "Then Moses and the Israelites sang this song. . . . They said: I will 
sing to the Lord" (Exod. 15:1), which is to say that they themselves composed it and sang it. Thus, at the end they prayed for their success: "Terror and dread descend upon them" (15:16), "You will bring them and plant them" $(15: 17)$. . . It was thus with the Song of the Sea, which Moses composed to praise and laud the God who answered him in the time of his distress, and for this Miriam his sister also composed a song with tambourines and dance, as explained further on. Indeed, these songs were written in the Torah and in the words of the prophets because God received them and favored them and commanded that they be written there. If so, the composition of this song was by Moses, and its inclusion in the Torah was from God. ${ }^{31}$

Abarbanel explains that the poetic texts in the Torah were divinely inspired; they were composed and sung by the prophets. Nonetheless, their inclusion in the Torah and the prophetic books was by divine command.

\section{Distinguishing between Different Types of Biblical Texts}

At this stage, it is worth noticing that the Rishonim identified and distinguished between different genres and the different content that they communicate. For example, the opening phrase "The Lord spoke to Moses, saying" is always understood as the narrator's introduction to the binding legal content spoken by God, while the narrative portions of the Bible begin with "When God began to create" (Gen. 1:1) expressed from the viewpoint of the narrator. Each style has a different role and status.

The poetic texts and the book of Deuteronomy attracted great attention because the sages sensed that the Torah did not present them as words that were spoken in the course of prophetic revelation. They discerned the singularity of the revelation at Sinai and similar revelations relative to the "regular" prophecy of Moses. Nachmanides and Abarbanel, whose words we have read above, faced a difficult contradiction: a narrow reading of the Torah creates the impression that it includes various genres from different times and revealed in different ways, in contrast to the model of "dictation" and equality. The solution they proposed was to distinguish between the creation process of the different parts of the Torah, and the process by which they were written. The different parts were revealed and took shape in a lengthy process and in various ways. It was only afterward that God commanded Moses to record these words in the Torah. 


\title{
Or ha-Ḥaim—Chaim ibn Attar
}

At the beginning of his commentary on Deuteronomy, Rabbi Chaim ibn Attar (1696-1743) went far beyond Nachmanides and Abarbanel in his distinction between the words that Moses wrote himself and the words he heard from God:

\begin{abstract}
"These are the words" (Deut. 1:1) — These exclude the preceding, which is to be interpreted as follows: Because it says "that Moses spoke," meaning that they are his own words, the entire book of rebuke is Moses' reproof of those who transgressed the word of God. Our sages said that the curses in Deuteronomy were spoken by Moses himself, and even where he repeated and interpreted the Lord's earlier statements he was not commanded to do so; rather, he himself repeated the words. ${ }^{32}$ Scripture took pains to say this because [one might think] that just as Moses spoke such words himself, so too in earlier speeches Moses said some things himself. Rather, he did not say even one letter himself of everything in the preceding four books of the Torah, only the words that came from mouth of the Commander in their original form, without any alteration, even adding or removing one letter. ${ }^{33}$
\end{abstract}

Ibn Attar's views contradict the "dictation" model. He states simply that the entire book of Deuteronomy is Moses' book; he was not commanded to reveal it, but rather spoke on his own accord. In spite of his strong words about the other books of the Torah, which Moses did not compose "even one letter himself," Ibn Attar recognizes the uniqueness of poetry, and claims that, after an appropriate preparation, Moses himself recited the Song of the Sea: "Then [Moses] sang' (Exod. 15:1) - It did not have to say 'then,' only 'Moses sang,' and it would be understood that [Moses and the Israelites] sang then. However, Scripture means to inform us of the preparation of the idea. For when the awe of [God's] majesty and full faith entered their hearts, then they merited to utter the song with divine inspiration." 34

\section{Beyond the "Dictation" Model}

All the commentators presented thus far agree with the "dictation" model, even though they sensed the Torah's different genres and the difficulties that their presence poses for this position. But the assumption that the entire Torah was dictated by God to Moses was a matter of dispute among 
the Rishonim. Rabbi Abraham Ibn Ezra (1092-1167) often alludes to this dispute, and Rabbi Judah Ha-Chasid (1140-1217) says so explicitly in his commentary. Rabbi Joseph ben Eliezer Bonfils (Tov Elem, 14th cent.), author of the Tzofnat Paneah, a supercommentary on Ibn Ezra, went so far as to differentiate among the genres in the Torah (Gen. 12:6), claiming that although the sections containing commandments were composed by God, prophets were allowed to add their own words to texts of other genres in order to explain and interpret them. ${ }^{35}$

\section{Reclaiming the Multi-Genre Perspective: Time to Reevaluate "Necessary Belief"}

In presenting the Torah as uniform and equal, Maimonides made an important contribution to Jewish belief. His view affirms the exalted and binding status of the Torah - a status that I would certainly never contest. In light of what we have seen, however, it seems to me that the time has come to revive the predominant view of the Rabbis, the posekim, and the commentators. This view identifies different genres in our Torah that testify to diverse facets of revelation and different levels of importance. In a passage that appears in Orot ha-Emunah and in Shemonah Kevatzim, Rav Kook distinguishes between two types of beliefs: "All beliefs can be divided into the two systems that Maimonides identified: true beliefs and necessary beliefs. The true beliefs are the foundation that sustains the principles of faith, and the necessary beliefs are like a peel protecting the fruit." 36

At times, one of the "necessary" beliefs becomes extraneous, and it may even harm true belief:

Sometimes it becomes imperative to banish one of the "necessary" beliefs from the sphere of faith, because the collective has already arrived at a level at which it no longer needs to be supported by this "necessary" part of the belief system. Then a kind of turbulence begins: from one angle, it looks like a breach of the foundation of the faith, while from the other it looks like a light appearing on the horizon of faith and a reinforcement of its foundations. And in fact, there is truth to both perspectives. ${ }^{37}$

My prayer is that the publication of these ideas will strengthen the foundations of faith, discarding beliefs that, while once necessary to protect true belief, now merely cause confusion. 


\section{Maharal: Two Views of the Torah}

The perspective of Rabbi Judah Loew of Prague (Maharal, 1520-1609) can serve as an opening to a broader view of the arc of literary genres found in the Torah, based on a complex picture of divine revelation.

The intention of this is not, God forbid, to say that Moses said something himself, even one letter. Only [to observe] the distinction between Deuteronomy and the rest of the Torah. For the Torah that blessed God gave to Israel contains two points of view: One point of view is that of God, who gave the Torah. The other point of view is that of Israel, which received the Torah. If one person gives something to his fellow and they are of equal standing, there is only one point of view, since both are at the same level. But when blessed God, who is above everything, gave the Torah to Israel, and they were on earth, it was impossible for there not to be a special point of view from the perspective of the giver and a different point of view from the perspective of the receiver. Therefore, the entire Torah, except Deuteronomy, which is the last book, is told from the point of view of the giver. Because the receiver receives at the end, after the giver has finished his decree; only then does the receiver receive. This is why Deuteronomy is called mishneh Torah [the reiteration of the Torah], as if it were a distinct thing, which is from the perspective of the receiver. And there is a particular point of view on the receiver's end, as it says in Deuteronomy: "Moses undertook to expound this Torah" (1:5), for the receiver needs more interpretation and explanation. And this is the distinction between the "Torah" [the first four books] and the mishneh Torah [Deuteronomy]. ${ }^{38}$

In prophecy, and even in Moses' prophecy, the Maharal sees an encounter between God and humanity. Prophecy is a phenomenon that will always have a divine facet and a human facet. On the basis of these words, albeit not necessarily in their original meaning, I would like to propose the following perspective, which allows us to read the Torah and be impressed by the full variety found in it.

The entire Torah is situated between the point of view of the giver and the point of view of the receiver, and the various genres that we identify in the Torah express particular points along the continuum of communication between the infinite and human beings. This observation enables a "close reading" of the 
Torah, free of apologetics, but guided by the fear of heaven. All reality stands between that which is given from heaven and human observation. Therefore, a human being can experience various points of contact between these two poles. I do not claim that these encounters, even sublime experiences of self-nullification or inclusion, are true prophecy. Prophecy is a special phenomenon. The prophet succeeds in expressing the will of God in an edict designed to shape and direct the behavior of all people. In contrast, other inspirational experiences are expressed morally, poetically, or artistically, but not normatively. In biblical prophecy, the prophet receives verbal messages that can be translated into practical guidelines. A plain reading of the Torah, without prior assumptions, inevitably leads to the conclusion that the Torah does not present itself as uniform, but rather the opposite: its various parts take the form of diverse literary genres that embody different facets of revelation.

This reading accords with the care that the Torah takes to note the context of a given revelation, such as, "The Lord called to Moses and spoke to him from the Tent of Meeting, saying" (Lev. 1:1), or the context of a prophetic speech, such as, "These are the words that Moses addressed to all of Israel” (Deut. 1:1). The care the Torah takes to distinguish genres reveals the significance of their different revelatory characters.

\section{Conclusion: The Value of Modern Biblical Scholarship}

It is critical to recognize the methods of biblical scholarship as interpretive tools in the toolbox of the Torah student, tools that can shed light on the Torah's composition and formation. Biblical scholarship can help us understand difficult passages that we otherwise would not have been able to interpret. On the other hand, we must not forget that these tools cannot judge the revelation of our holy Torah. Science is a technical tool; it does not have the capacity to determine the value and meaning of the things it investigates.

An analysis of the historical formation of our Torah can never touch the secret of the encounter between humanity and God. Even after many years in which cultures changed and new scientific tools were developed, the individual who ties his soul to the Torah is able to experience something of this encounter. Biblical scholarship does not impinge on the exalted stature of the Torah, just as the study of art is not able to expose the inspiration behind painting, musical composition, literature, and poetry.

What theology, then, is relevant in our generation, and how can we direct our students toward it? It seems to me that there is no other option but to let 
go of the "dictation" model, which does not accord with the simple meaning of the biblical texts or modern biblical scholarship. Prophecy is communication between God and humanity, so it is inevitable that our Torah should contain echoes of the language and culture of the time when it was revealed. ${ }^{39}$ Even the Torah, which was given as a foundational and binding document, is not an exception to this rule. Rabbinic literature offers a key to an appropriate view of revelation: "The Torah speaks in the language of human beings." 40 This indicates that communication between the infinite and humanity is tied up in human language and constrained by human limitations, especially the limitations of time and place. ${ }^{41}$ But when there is a notion of absolute difference between God and humanity, this view only causes surprise.

This notion, which is pervasive in many circles of Western philosophy in our time, need not discourage us from expressing the view that there can be encounters with the sublime, the mysterious, and the wondrous. There is no reason to renounce the traditional view that our Torah is a prophetic document with no peer in human history. Our Torah is a faithful expression of God's will, translated into human language, with all that it entails. The process of its creation is complex, and includes different prophetic moments that occur in the wondrous course of communication between God and the human beings created in His image and likenes

\section{Endnotes}

The author would like to thank Ilan Wolff for helping prepare the English version.

1. For some other approaches to the "dictation" problem, see Samuel Fleischacker, "Making Sense of the Revelation at Sinai," TheTorah.com, accessed September 12, 2016, http://thetorah.com/making-sense-of-the-revelation-at-sinai/; and Baruch Schwartz, “"The Lord Spoke to Moses'-Does God Speak?,” TheTorah.com, accessed September 12, 2016, http://thetorah.com/does-god-speak/.

2. The original Hebrew is mehokek; the term also means "lawgiver."

3. Moshe Feinstein, Sefer Iggerot Moshe (New York: M. Feinstein, 1985), 6:358-359 (Yoreh Deah, pt. 3, §114, s.v. she-kibalti me-aher).

4. The translation is adapted from Maimonides, Commentary on the Mishnah: Tractate Sanhedrin, trans. Fred Rosner (New York: Sepher-Hermon Press, 1981), 155.

5. Mishnah, tractate Sanhedrin 10:1. The translation is adapted from Herbert Danby, trans., The Mishnah (Oxford: Oxford University Press, 1933), 397.

6. A baraita is a traditional interpretation or statement of biblical law from the mishnaic period not incorporated in the Mishnah.

7. Babylonian Talmud, tractate Sanhedrin 99a.

8. Babylonian Talmud, tractate Bava Batra 15a.

9. Maimonides, Teshuvot ha-Rambam, ed. Joshua Blau (Jerusalem: Reuven Mass, 1989), 498 ("Laws of Prayer and the Priestly Blessing," 12:263). 
10. Jerusalem Talmud, tractate Berakhot 1:5.

11. See the commentary of Rabbi Nissim Gaon and Rashi on Babylonian Talmud, tractate Berakhot 12a; Sefer Abudirham, "Laws of Recitation of Shema," in Abarbanel ha-Shalem (Jerusalem: Usha, 1963), 84-85. See also Yechezkel ben Yehuda Landau, Tselah ha-Shalem (Jerusalem: Vagshal, n.d.), 48, on Babylonian Talmud, tractate Berakhot 12a, s.v. sham lemikba'inhu be-Nehardea vekhuleh.

12. Rashbah, Sefer Sheilot va-Teshuvot (Jerusalem: Mechon Tiferet ha-Torah, 1990), 86 (1:184), 123 (1:289).

13. Mekhilta de-Rabbi Yshmael, Yitro, de-be-hodesh, parashah 4.

14. Midrash Eikhah Rabbah, ed. Salomon Buber, parashah 1.

15. Pesikta de-Rav Kahana, ed. Bernard Mandelbaum, parashah 2 (Ki Tetse').

16. In modern scholarship, there is also a debate over the status of the Decalogue. Moshe Weinfeld claims that "among all the laws, only the list of commandments in the Decalogue is perceived as foundational and primary in the establishment of a connection between God and Israel. It was only the Decalogue that the Israelites merited hearing straight from the Deity's mouth." See his "Uniqueness of the Decalogue and its Place in Jewish Tradition," in The Decalogue in History and Tradition, ed. B. Z. Segal (Jerusalem: Magnes, 1990), 1-34. Yair Hoffman claims to the contrary that there are no explicit references to the Decalogue in the Bible except in three places, and that the supposed echoes of them are not conclusive. See his "The Status of the Decalogue in the Hebrew Bible," in The Decalogue in Jewish and Christian Tradition, eds. H. G. Reventlow and Y. Hoffman (New York: T\&T Clark, 2011), 32-49.

17. Jerusalem Talmud, tractate Megillah 3:7.

18. Babylonian Talmud, tractate Megillah $31 \mathrm{~b}$.

19. Babylonian Talmud, tractate Sanhedrin 99a.

20. Nachmanides discussed this in his introduction to Genesis (Torat Hayim: Hamiseh Humshei Torah, ed. Mordechai Katzenelenbogen [Mosad Harav Kook, 1986], 15-19), and Don Isaac Abarbanel also discussed it extensively at the beginning of his commentary on the book of Deuteronomy. See, e.g., his comments on the opening words of Deuteronomy (Perush al ha-Torah [Jerusalem: Benei Abarbanel, 1963], 8). His contemporary, Rabbi Isaac b. Rabbi Joseph Karo, uncle of Rabbi Joseph Karo, discussed it repeatedly in his book Toldot Yitzhak (Jerusalem and Bnei Brak: Siah Yisrael, 1981). See, e.g., his discussions of Deuteronomy, beginning on p. 138, and elsewhere.

21. See Ran's comment on the Rif to Babylonian Talmud, tractate Megillah 11a, s.v. Hallalu Moshe mi-pi atsmo amran.

22. Midrash Va-yikra Rabbah, ed. Mordechai Margoliot, parashat Va-yikra', 1. See also Eliyahu Rabbah, ed. Meir Ish-Shalom, parashah 7. And Avot de-Rabbi Natan, A, 1: "The Torah was given by Moses at Sinai, as it says: 'He inscribed them on two tablets of stone, which He gave to me' (Deut. 5:19). And further on it says: 'These are the laws, rules, and instructions that the Lord established, through Moses on Mount Sinai, between Him and the Israelite people' (Lev. 26:46)."

23. Babylonian Talmud, tractate Hagigah 6a; Babylonian Talmud, tractate Sotah 37b.

24. Sifrei Devarim, parashat Ha'azinu, 306.

25. Kohelet Rabbah 5:2, 27; likewise, Shemot Rabbah, ed. Avigdor Shinan, parasahat Va-era', 10. And it would be impossible not to cite the Babylonian Talmud, tractate Menahot 29b, which describes Moses' visit to Rabbi Akiva's house of learning; the latter refers to a law that he is teaching, which Moses does not recognize or understand, as "law of Moses from Sinai," and it is clear that this is not a historical description. See Shmuel Safrai, "Halakhah le-Moshe 
me-Sinai: Historiah o Teologiah?” (The law of Moses from Sinai: History or Theology?), in Mehqerei Talmud 1, ed. Yaacov Sussman and David Rosenthal (Jerusalem: The Magnes Press, 1990), 11-38. In his treatment of the Gemara in Menahot, Safrai writes: "Moses does not understand even the very law that Rabbi Akiva calls a 'law of Moses from Sinai' because Rabbi Akiva innovated in the law, and because they refer to words of Torah as the "law of Moses from Sinai.' This means that everything that is created and erected as a Jewish law has its origin in the law of Moses, and it is a continuation of the course of the Torah and law that was given to Moses at Sinai and spoken at Horeb."

26. Jerusalem Talmud, tractate Kilayim 2:27; see also Jerusalem Talmud, tractate Terumot 2:41; Jerusalem Talmud, tractate Shabbat 1:3 and 10:12; Jerusalem Talmud, tractate Nazir 7:56.

27. Babylonian Talmud, tractate Hagigah $3 \mathrm{~b}$.

28. Rosh, Piskei ha-Rosh, tractate Niddah, "Laws of Ritual Baths," 1, and following.

29. The translation is adapted from Nachmanides, Commentary on the Torah, trans. Charles B. Chavel (New York: Shilo Publishing House, 1971).

30. My general impression from reading his commentary is that Nachmanides recognizes the uniqueness and special significance of different parts of the Torah. I hope to return to this subject in the future.

31. Abarbanel on Exod. 15. He offers a similar explanation of parashat Ha'azinu (Deut. 32, ad loc.)

32. See Babylonian Talmud, tractate Megillah 31b.

33. Chaim ibn Attar, Sefer Or ha-Haim (Jerusalem: A. Blum, 1990), 1 (Deut. 1:1).

34. Chaim ibn Attar, Sefer Or ha-Haim, 89 (Exod. 15:1).

35. This is also the way Rabbi Bonfils understands the passage in tractate Sanhedrin. See Zev Farber, "The Significance of Ibn Ezra's Position that Verses were Added to the Torah," TheTorah.com, accessed September 26, 2016, http://thetorah.com/the-significance-of-ibn-ezras-position/; and "Seven Torah Passages of Non-Mosaic Origin according to Ibn Ezra and R. Joseph Bonfils," TheTorah.com, accessed September 26, 2016, http:// thetorah.com/non-mosaic-torah-passages-ibn-ezra-and-bonfils/.

36. See Maimonides, The Guide of the Perplexed, 3:28. See also Rav Avraham Yitzhak Hacohen Kook, Orot ha-Emunah (Jerusalem: Me-alef ve-ad Tav, 1998), 48.

37. Kook, Orot ha-Emunah, 48.

38. Maharal, Sefer Tiferet Yisrael, chap. 43.

39. See the chapters on prophecy in Maimonides, The Guide of the Perplexed, 2:32-39. See also Rabbi Joseph Albo, Sefer ha-Ikarim (Jerusalem: Feldheim, 2011), 290-294, 328-332 (ma'amar 3, chaps. 9 and 17).

40. This quote appears frequently, beginning with texts from tannaitic times. See, for instance, Babylonian Talmud, tractate Nedarim 3a.

41. See the article of my student Dr. Chezi Cohen in this volume. My position is similar to his. 